\title{
Increased Levels of Hemoglobin-derived and Other Peptides in Alzheimer's Disease Cerebellum
}

\author{
J. Randall Slemmon, ${ }^{1,2}$ Candice M. Hughes, ${ }^{2}$ Gregory A. Campbell, ${ }^{1}$ and Dorothy G. Flood ${ }^{2,3}$ \\ Departments of 'Biochemistry, ${ }^{2}$ Neurobiology and Anatomy, and ${ }^{3}$ Neurology, University of Rochester Medical Center, \\ Rochester, New York 14642
}

\begin{abstract}
Several studies point to the importance of peptides and proteolysis in Alzheimer's disease (AD). Because of its ability to study small proteins and peptides, reverse-phase HPLC was employed to study these species in AD. Cerebellum was chosen for these initial studies because it does not show significant neuronal loss but does show some pathology in AD. Examination of over 600 peptide peaks per case revealed 15 that were elevated in AD. Nine were fragments of hemoglobin, and the remainder included two species of calmodulin, two of myelin basic protein, and one each of 67 kDa neurofilament proteimand PEP-19. The cleavage sites on hemoglobin were after hydrophobic residues and immunolocalization was seen preferentially around blood vessel walls and granule cells. The elevation of the non-serumderived peptides was characteristic of general metabolic changes that occurred in AD cerebellum, and the presence of elevated hemoglobin polypeptides indicated either possible disruption of the blood-brain barrier or selective evasion of it by peptidaceous products. Further studies are required to establish whether hemoglobin fragments have a role in neurodegenerative processes such as AD.
\end{abstract}

[Key words: Alzheimer's disease, cerebellum, proteolysis, blood-brain barrier, hemoglobin, immunocytochemistry, HPLC, PEP-19, calmodulin, neurofilament protein, myelin basic protein]

Biological organisms produce a large number of peptides and small proteins, many of which are processed from precursors by limited proteolysis. This class of molecule performs a wide variety of functions, including both well-known ones such as that of the peptide hormones and neuromodulators, and others that are not yet well understood. The latter class of peptide is especially relevant to diseases of the nervous system. For example, the $\beta / \mathrm{A} 4$ fragment of the amyloid precursor protein is a major component of senile plaques in Alzheimer's disease (AD; Selkoe, 1991), and peptide sequences from the precursor have exhibited toxicity (Yankner et al., 1989; Koh et al., 1990) and/or survival-enhancing activities (Saitoh et al., 1989; Whitson et al., 1989; Milward et al., 1992) on cultured cells. Other

\footnotetext{
Received Oct. 19, 1992; revised June 11, 1993; accepted Oct. 7, 1993.

This work was supported by R35 AG09016 from NIH. We thank the members of the Rochester Alzheimer's Disease Project (AG03644) and Alzheimer's Disease Center (AG08665) for the clinical and neuropathological diagnosis of the cases used in this study and for making this tissue available.

Correspondence should be addressed to J. Randall Slemmon, Department of Biochemistry, Box 607, University of Rochester Medical Center, 601 Elmwood Avenue, Rochester, NY 14642.

Copyright (C) 1994 Society for Neuroscience $0270-6474 / 94 / 142225-11 \$ 05.00 / 0$
}

peptidaceous species that contribute to the core of amyloid deposits include IgG and albumin (Ishii et al., 1975; Ishii and Haga, 1976; Wisniewski and Kozlowski, 1982) and $\alpha_{1}$-glycoprotein (Kalaria and Grahovac, 1990). The $9 \mathrm{kDa}$ peptide fragment of the plasma form of gelsolin, a protein responsible for depolymerizing actin in a calcium-dependent manner, is similarly associated with amyloid deposits in cases with familial amyloidosis of the Finnish type (Haltia ct al., 1990). Even with the intensified interest in peptide/protein processing and its role in neurodegenerative diseases, the pathways by which these species are formed and deposited are unknown.

In addition to the robust deposition of peptides into diffuse and compact amyloid plaques, there is growing evidence that altered protease activities are involved in AD that could potentially generate these peptides. Pertinent examples include calpain I, which is able to process the amyloid precursor protein via a calcium-dependent mechanism (Siman et al., 1990). There are also more general protease activities that have been found to be specifically elevated in $\mathrm{AD}$, such as metalloproteases in the hippocampus, capable of degrading tissue matrix constituents (Backstrom et al., 1992). In parallel with altered protease activities, protease inhibitors are also implicated as part of the disease process. For example, $\alpha_{1}$-antichymotrypsin has been localized to senile plaques and diffuse plaques ( $\Lambda$ braham et al., 1988). It may also be relevant that the amyloid precursor protein is itself capable of inhibiting factor XIa, a protease that participates in the blood coagulation cascade (Smith et al., 1990).

This widespread association of peptides and the proteolysis that produces them with AD has encouraged the use of experimental approaches that can directly characterize these components from tissues, regardless of whether they were produced locally or transported from other regions. To this end, a methodology hased on HPI C C analysis of peptides has been developed that can broadly examine acid-soluble species in samples of brain tissue (Slemmon and Flood, 1992). Employing this approach, peptide composition in postmortem cerebellum was examined in AD. Cerebellum, unlike regions of cerebral cortex, does not appear to show significant neuronal loss but does show Alzheimer's changes (plaque formation). Therefore, peptide changes would not reflect alterations in cellular composition of the tissue but rather functional changes induced by AD. Additionally, this brain region provided ample material for peptide isolations.

\section{Materials and Methods \\ Human subjects}

Cases consisted of six confirmed AD and six neurologically normal controls, three males and three females in each group. All cases were 
obtained at autopsy through the Rochester Alzheimer's Disease Project (RADP) and Center (ADC). Anterior cerebellum of the left side was frozen on dry ice immediately upon dissection and stored at $-80^{\circ} \mathrm{C}$. Anterior cerebellum of the right side was fixed in phosphate-buffered formalin solution made with half $10 \%$ formalin and half $4 \%$ paraformaldehyde solutions. All cases in the AD group had a clinical history of progressive dementia that was confirmed by neuropathological examination at death. The AD cases were free from other neurological and psychiatric illnesses and from other neuropathological findings at autopsy. Control cases had a clinical history lacking in any neurological or psychiatric disorder, and showed no significant neuropathology at death. The pathological severity of Alzheimer's changes, when present in the controls, was within established age-adjusted criteria for normal elderly subjects (Khatchaturian, 1985). None of the cases had a history of alcohol abuse. The clinical histories of the controls and four of the $\mathrm{AD}$ cases were obtained retrospectively from health care workers, medical records, and family members. The remaining AD cases were followed clinically prior to their deaths by the Clinical Core of the RADP/ ADC. Average postmortem delay intervals were $13.45 \mathrm{hr}$ (range, 9-19 $\mathrm{hr}$ ) and $11.33 \mathrm{hr}$ (range, 5-16 hr) for controls and AD cases, respectively. Average age at death for the AD cases was 77.0 years (range, 74-83) and 80.2 (range, 73-86) for the controls. Neither postmortem delay interval nor age at death varied significantly between the groups $(t=$ $0.98, \mathrm{df}=10, p>0.05$ for postmortem delay; $t=1.32, \mathrm{df}=10, p>$ 0.05 for age at death). Average duration of illness for AD cases was 8.7 years (range, 5-11 years). The average brain weight for AD cases was $1087 \mathrm{gm}$ and for the controls was $1297 \mathrm{gm}(t=3.47, \mathrm{df}=10, p<0.01)$. A 36-year-old control died of myocardial infarction, had a postmortem delay of $5 \mathrm{hr}$, and was used only in the immunocytochemical study.

\section{Peptide analysis}

Preparation of crude peptide pools. Samples of frozen human cerebellum were broken into smaller pieces in a mortar with a pestle sitting in dry ice. Approximately $1 \mathrm{gm}$ of the frozen tissue pieces from each case was placed into vials and held for homogenization. Homogenization of the tissue and fractionation of the acid-soluble peptides into crude pools with conventional size exclusion and ion-exchange chromatography were accomplished as described in Slemmon and Flood (1992). Briefly, the frozen tissue samples were added to $50 \mathrm{ml}$ of hot $\left(\approx 80-90^{\circ} \mathrm{C}\right) 250 \mathrm{mM}$ sodium phosphate, $\mathrm{pH} 2.5$, and dispersed as a $2 \%(\mathrm{w} / \mathrm{v})$ homogenate with a Tekmar Tissumizer (S25KR probe). After an approximately 30 sec homogenization, the samples were placed in a boiling water bath for $5 \mathrm{~min}$. The boiled samples were then centrifuged at $40,000 \times \mathrm{g}$ for $20 \mathrm{~min}$ at $22-24^{\circ} \mathrm{C}$. The supernatants were recovered and the peptides were desalted and concentrated by chromatography on two Waters C1 8 SepPak cartridges attached in series (Environmental SepPak, $1 \mathrm{gm}$ bed). The cartridges had been preequilibrated in $0.1 \%$ trifluoroacetic acid, $99.9 \%$ water, and the absorbed peptides were eluted with $0.1 \%$ trifluoroacetic acid, $29.9 \%$ water, $70 \%$ acetonitrile. Eluted material was taken to dryness in a Savant SpeedVac, reconstituted in $0.1 \%$ trifluoroacetic acid:water, and chromatographed on a $1.5 \times 18 \mathrm{~cm}$ column of Sephadex G-50 fine equilibrated in $0.1 \%$ trifluoroacetic acid in water. The peptides in the voided and included volumes were collected separately. The higher-molecular-weight peptides in the void volume were held for later analysis, and the included peptides were again concentrated and dried. These lower-molecular-weight peptides from the included volume were then reconstituted and fractionated into anionic, cationic, and neutral peptide pools on Waters Accell QMA and CM columns as described in Slemmon and Flood (1992).

HPLC analysis of peptide pools. All of the crudely fractionated peptide pools, including those voided on Sephadex G-50, were then subjected to high-resolution analysis on reverse-phase high-pressure liquid chromatography (RP-HPLC) in $0.1 \%$ trifluoroacetic acid, water with acetonitrile as the mobile phase. The column used was a Vydac $\mathrm{C} 18(0.46$ $\times 25 \mathrm{~cm}, 1.0 \mathrm{ml} / \mathrm{min}$; The Separations Group, Hesperia, CA). RPHPLC analysis was carried out on a high-pressure binary system (LDC, Riviera Beach, FL) equipped with automated sample injection and twochannel data acquisition. Channel 1 collected the signal from a Waters 441 absorbance detector and channel 2 monitored a Gilson model 121 fluorometer, which was part of a post-column fluorescent detection system. The total number of chromatographic traces per tissue sample was eight (four peptide fractions times two detection systems). Each set of eight traces yielded about 600-700 peptide peaks, for a total of about 9000 peptide peaks from the 12 tissue samples. Because of this large number of peptide peaks, the complexity of the HPLC traces, and the need to compare homologous peaks across tissue samples in a quantitative manner, several computer programs were employed for initially examining the data. These included the AxxIOM 727 chromatographic software (Axxiom Chromatography, Moorpark, CA) and programs written in the SAS (SAS Institute, Cary, NC) programming language and described elsewhere (Slemmon and Flood, 1992). Their purpose was to identify and quantify all peptide peaks and then sort homologous peaks across tissue samples into spreadsheets for final analysis. Peptide peaks that were identified by the computer-assisted analysis as showing consistently altered expression as a function of $\mathrm{AD}$ were then inspected visually, in order to determine that they were well-resolved species.

Peptide sequencing. Peptide species were identified by comparing partial amino acid sequence from the peptide against the GenBank and EMBL sequence data bases (Devereux et al., 1984). Peptide sequencing was performed on peptide peaks collected from parallel HPLC separations that did not employ post-column modification of peptides with Fluorescamine. If material was sufficient, up to one-half of a peptide sample from HPLC was subjected to sequencing on an Applied Biosystems model $477 / 120$, using a polybrene-treated glass fiber filter for immobilizing the sample to be sequenced. If the intact peptide failed to yield sequence, material was limited, or more sequence information from a peptide was desired, then the intact peptide was fragmented with trypsin and the tryptic fragments were submitted for sequencing. In general, tryptic fragments yield readable sequence at significantly lower levels than can be achieved with intact material, since they are more homogeneous and cause less background upon phenylthiohydantoin (PTH)-amino acid analysis. Unfortunately, however, amino-terminal sequence that can place the cleavage site that generated the peptide from the parent polypeptide is lost. Trypsinization was carried out on peptides as follows. L-1-Tosylamide-2-phenylethyl chloromethyl ketone (TPCK)treated trypsin (2 mg; Cooper Biochemicals, Torrey Pines, CA) was separated on a Vydac $\mathrm{C} 4$ column using $0.1 \%$ trifluoroacetic acid:water and acetonitrile as the mobile phase. The doublet emerging at approximately $38 \%$ acetonitrile was collected as the active intact trypsin $(\approx 140$ $\mu \mathrm{g})$. The large, broad peak following this doublet was presumably chymotrypsin, and was discarded. Protein concentration of the trypsin sample was estimated by its absorbance at $280 \mathrm{~nm}$ using an extinction coefficient of $1.0 \mathrm{AU} / \mathrm{mg}$ protein. One microgram of trypsin was added to a peptide sample in $50 \mu \mathrm{l}$ of tris(hydroxymethyl)aminomethane-trifluoroacetic acid, $\mathrm{pH} \sim 8-8.5$, and placed at $37^{\circ} \mathrm{C}$ for $18-20 \mathrm{hr}$. Cytochrome $C$ (horse heart, Sigma Chemical Co., St. Louis, MO) was used in parallel digestions to serve as a positive control for the trypsin digest. Residual amounts of guanidine $\mathrm{HCl}$, often used when drying peptide samples, were found to inhibit the HPLC-purified trypsin and were avoided. Tryptic fragments from the digests were separated on Vydac C18 columns $(0.21 \times 25 \mathrm{~cm}, 200 \mu \mathrm{l} / \mathrm{min})$ using the same buffer system as for the peptide separations described above. Peptide peaks were collected and directly applied to filters for sequencing.

\section{Analysis of $\alpha$ - and $\beta$-hemoglobin polypeptides on RP-HPLC proflles of high-molecular-weight peptides from cerebellum}

Additional aliquots of high-molecular-weight peptides from samples shown in Figure 1 were spiked with either the $\alpha$ - or $\beta$-chain of hemoglobin in order to identify these species in the HPLC profile. HPLCpurified hemoglobin subunit polypeptides were prepared by boiling 1 $\mathrm{mg}$ of human hemoglobin (Sigma) in $250 \mathrm{~mm}$ sodium phosphate, $\mathrm{pH}$ 2.5 , for $5 \mathrm{~min}$. The boiled sample was then subjected to RP-HPLC separation, which essentially yielded only two peaks. Amino-terminal sequencing identified the earlier eluting peak as $\beta$-hemoglobin and the later as $\alpha$-hemoglobin. Aliquots from these peaks were added separately to aliquots of the cerebellar high-molecular-weight peptides and additional RP-HPLC separations were carried out.

\section{Western blotting}

Homogenate proteins were prepared by dispersing and boiling frozen human cerebellum in sodium dodecyl sulfate-containing sample buffer. Supernatants were prepared by homogenizing samples of human cerebellum in $50 \mathrm{~mm}$ tris(hydroxymethyl)aminomethane $(10 \% \mathrm{w} / \mathrm{v})$ and centrifuging at $4^{\circ} \mathrm{C}$ for $20 \mathrm{~min}$ at $30,000 \times \mathrm{g}$. Protein samples were separated on polyacrylamide gel electrophoresis in sodium dodecyl sulfate (12.5\% acrylamide) on a Bio-Rad MiniProtean II, essentially following the directions of the manufacturer. Proteins were transferred from the gels to Immobilon P (Millipore) in $10 \mathrm{~mm}$ (3-[cyclohexylamino]- 


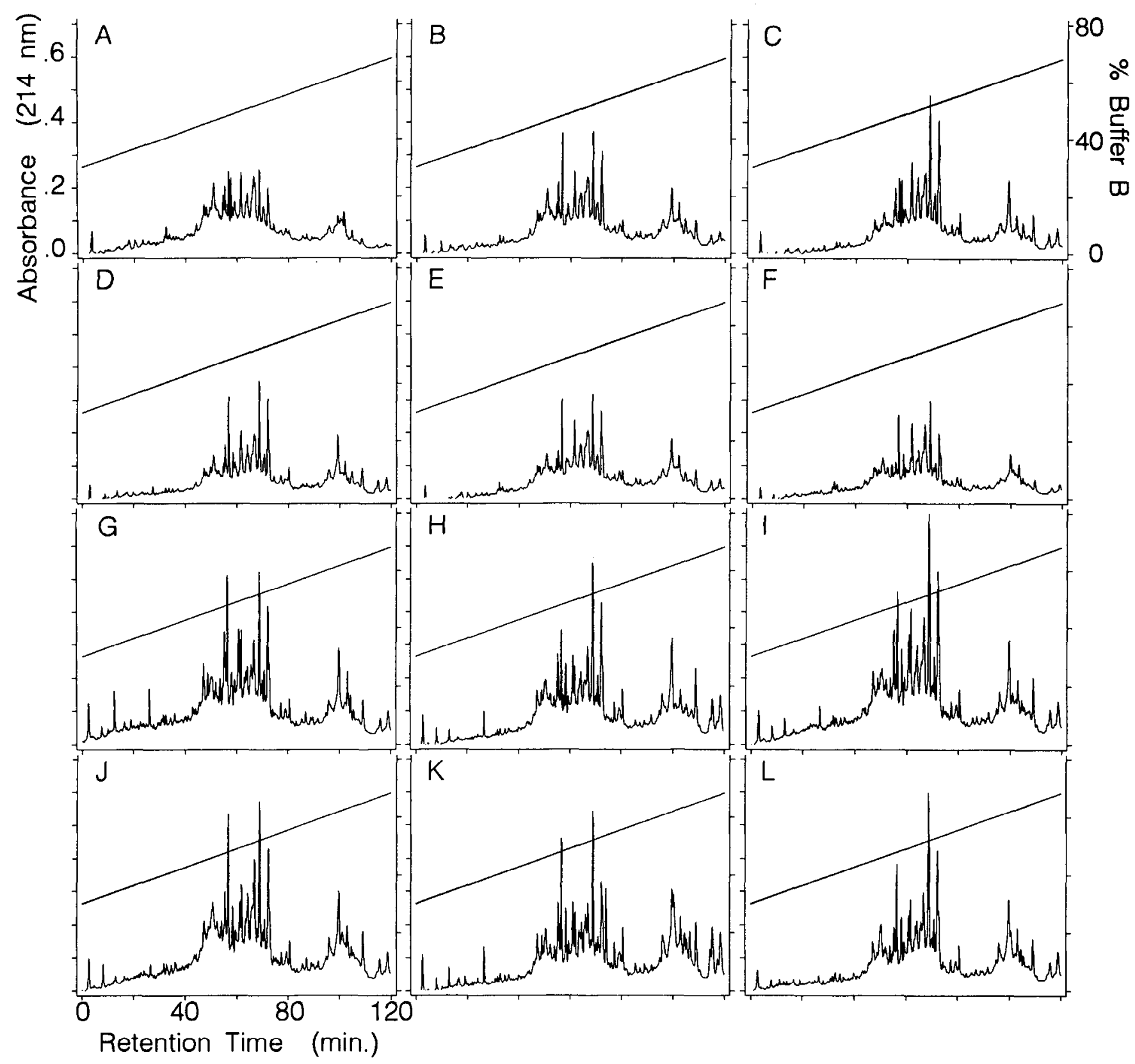

Figure 1. RP-HPLC separation of acid-soluble peptides in the high-molecular-weight fraction from cerebellum using detection by UV. $A-F$ are from neurologically normal cases, and $G-L$ are from pathologically confirmed AD cases. Buffer B was $70 \%$ acetonitrile, $29.9 \%$ water, $0.1 \%$ trifluoroacetic acid, and buffer $A$ was $99.9 \%$ water, $0.1 \%$ trifluoroacetic acid used at a flow rate of $1.0 \mathrm{ml} / \mathrm{min}$. The preparation of the peptide pool, the HPLC protocol, and the computer-assisted peak identification and comparison are detailed in Materials and Methods and in Slemmon and Flood (1992).

1-propanesulfonic acid) sodium, pH 11 , and $10 \%$ methanol in a Hoefer Mighty Small transfer apparatus at $0.5 \mathrm{~A}$ for $20 \mathrm{~min}$. Small dots of peroxidase-conjugated antisera were applied with toothpicks to the corners of the blot so that they would be visible both with the proteins and on the Western blot film image. This served to orient the superimposition of the two images so that the positions of the molecular weight markers could be determined for the Western blot image. Proteins were stained on the blot with $0.1 \%$ Coomassie blue in $50 \%$ methanol, $10 \%$ acetic acid for $5 \mathrm{~min}$ and destained in the same solution without the dye. Destaining was stopped by placing the blot in water, followed by blocking in 5\% Carnation nonfat dry milk in $50 \mathrm{~mm}$ tris(hydroxymethyl)aminomethane $\mathrm{HCl}$. Rabbit anti-hemoglobin sera (Sigma) at $1000 \times$ dilution was added to blocking solution where the nonfat milk was replaced with $5 \mathrm{mg} / \mathrm{ml}$ ovalbumin and placed on the blot for $2 \mathrm{hr}$ at $23^{\circ} \mathrm{C}$. The blot was then washed with three $10 \mathrm{~min}$ changes of blocking buffer and then a $20,000 \times$ dilution of peroxidase- conjugated goat anti-rabbit IgG (Pierce Chemical Co., Rockford, IL) in blocking buffer was placed on the blot for $1 \mathrm{hr}$. After a final series of three washes, the blot was rinsed in blocking buffer without the nonfat dry milk and then developed in Amersham ECL reagent (Amersham Life Science, Buckinghamshire, England). The bands were then visualized by exposure to $x$-ray film.

\section{Tissue localization of hemoglobin}

Preparation of antibodies to human hemoglobin. Whole antisera against human hemoglobin were obtained from Sigma. Total IgG was isolated from whole sera by first diluting the sera $1: 1$ in 140 mm sodium phos-

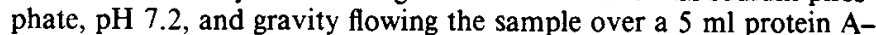
agarose column (Pierce) at $1 \mathrm{ml} / \mathrm{min}$. The column was washed until absorbance at $280 \mathrm{~nm}$ dropped to baseline, and the $\mathrm{IgG}$ fraction was eluted by introducing $100 \mathrm{~mm}$ sodium citrate, $\mathrm{pH} \mathrm{3.0,} \mathrm{to} \mathrm{the} \mathrm{column.}$ 
Figure 2. Peaks that were identified in the computer-assisted analysis as having peak heights that were all greater in the $A D$ cases than in the age-matched controls. The chromatogram is taken from Figure $1 l$. Peak numbers preceded by $H b$ are fragments derived from hemoglobin, and the peaks with only integers are not hemoglobin related. Table 1 provides the cumulative peak information for homologous peaks across all cases. Similar analysis of all other crude peptide pools (i.e., anionic, cationic, and neutral low-molecularweight peptides) from these tissues did not reveal homologous peptide peaks where there was no overlap in values between $\mathrm{AD}$ and control cases.

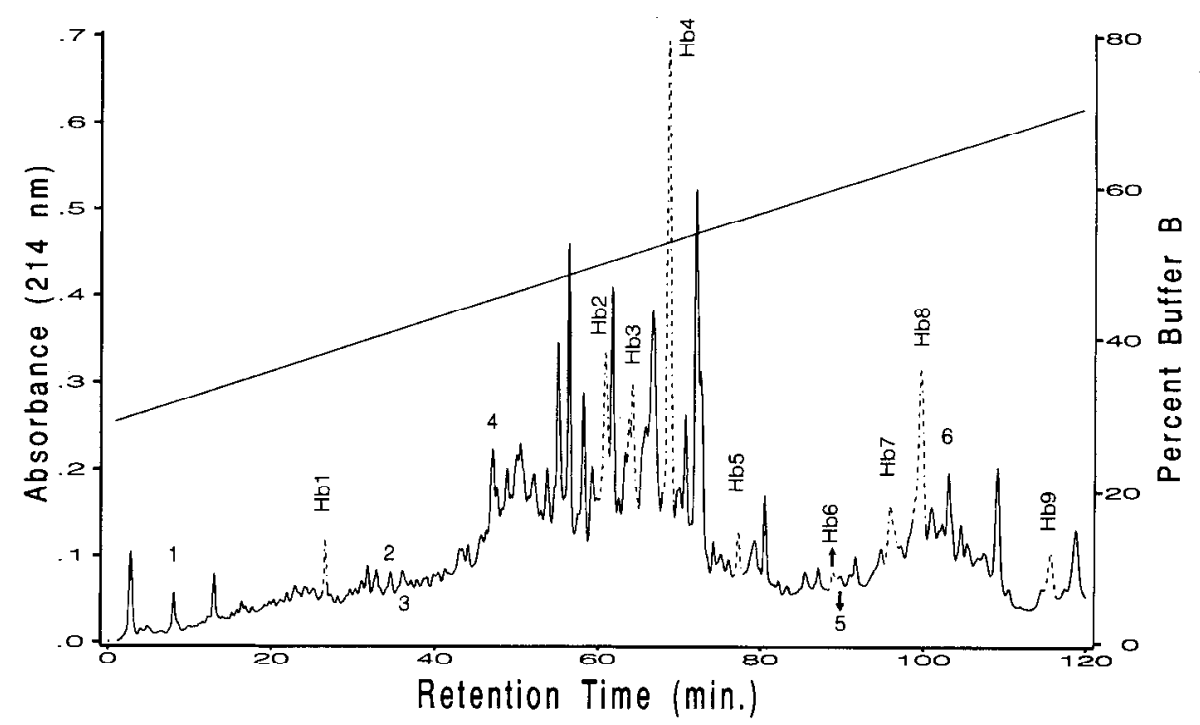

The IgG was neutralized immediately with the addition of $1 \mathrm{M}$ tris(hydroxymethyl)aminomethane in a dropwise manner. The sera yielded approximately $9 \mathrm{mg}$ of $\mathrm{IgG}$ per milliliter. A fraction of the purified IgG was preadsorbed against human hemoglobin that had been covalently coupled to Reacti-Gel 6 X (Pierce) to serve as the preadsorbed control antibody. The solid phase hemoglobin was prepared by dissolving $20 \mathrm{mg}$ of human hemoglobin in $2 \mathrm{ml}$ of $100 \mathrm{~mm}$ sodium borate, $\mathrm{pH} \mathrm{9.0,} \mathrm{and} \mathrm{combining} \mathrm{this} \mathrm{with} 2 \mathrm{ml}$ of a 1:1 slurry of the Reacti-Gel in the same buffer. The reaction was left at $22-24^{\circ} \mathrm{C}$ overnight with gentle mixing, after which the gel was washed first with $50 \mathrm{ml}$ of distilled water, then $25 \mathrm{ml}$ of $6 \mathrm{M}$ guanidine $\mathrm{HCl}$, followed by $50 \mathrm{ml}$ of $140 \mathrm{~mm}$ sodium phosphate, $\mathrm{pH}$ 7.2. Purified and $\mathrm{pH}$-neutralized $\mathrm{IgG}$ was left to incubate on the column for $30 \mathrm{~min}$ at $22-24^{\circ} \mathrm{C}$, and then the unbound IgG was recovered by continuing the column flow. The portion of the IgG that had not been exposed to the hemoglobin column was diluted (usually about $1.5 \times$ ) in order to make the IgG concentrations the same. These antibody reagents were then used directly for the immunocytochemical localization of hemoglobin-like immunoreactive material in tissue sections.

Immunocytochemistry. Blocks of fixed anterior cerebellum from the same cases as used for the peptide analysis as well as from a younger control were paraffin embedded. Sections were cut at $6 \mu \mathrm{m}$, mounted on slides, and rehydrated. Since red blood cells within the vasculature contribute considerable non-antibody-mediated peroxidase activity, sections were first treated with $0.1 \mathrm{M}$ sodium metaperiodate in $0.1 \mathrm{M}$ tris(hydroxymethyl)aminomethane, $0.75 \mathrm{M}$ sodium chloride, $\mathrm{pH} 7.2$ for $20 \mathrm{~min}$. at $22-24^{\circ} \mathrm{C}$ to suppress the endogenous activity. Free aldehydes were reduced by incubating the sections in $0.1 \%$ sodium metaperiodate and $0.1 \mathrm{M}$ sodium borohydrate in $10 \mathrm{~mm}$ phosphate-buffered saline (pH 7.4) for $30 \mathrm{~min}$. For localization of hemoglobin-like immunoreactivity, sections were then incubated in the phosphate saline buffer containing $1 \%$ (w/v) Carnation instant nonfat dry milk. Following washing, sections were incubated in purified total IgG with titer to hemoglobin at a concentration of $5 \mu \mathrm{g} / \mathrm{ml}$ in the phosphate saline buffer containing $0.1 \%$ Triton X-100 and $0.1 \%$ bovine serum albumin. Primary antibody incubations were allowed to proceed at $22-24^{\circ} \mathrm{C}$ overnight. Localization of bound primary antibody was accomplished using the Vectastain Elite kit (Vector Laboratories, Burlingame CA) according to the manufacturer's protocol. Sections were dehydrated through a series of alcohol solutions of increasing concentration and then mounted in DPX and coverslipped.

\section{Results}

Analysis of peptide profiles from postmortem cerebellum

The peptide profiles of the high-molecular-weight species, as well as the neutral, anionic, and cationic species from the low-

Table 1. High-molecular-weight peptides elevated in AD cerebellum

\begin{tabular}{|c|c|c|c|c|c|}
\hline \multirow[b]{2}{*}{ Peak } & \multirow[b]{2}{*}{ Source protein } & \multirow[b]{2}{*}{ Tryptic-fragment sequence } & \multirow{2}{*}{$\begin{array}{l}\text { Percentage } \\
\text { change of mean } \\
\text { (AD/control) }\end{array}$} & \multicolumn{2}{|c|}{ Peak height range $(\mu \mathrm{V})$} \\
\hline & & & & $\mathrm{AD}$ & Control \\
\hline $\mathrm{Hbl}$ & $\alpha$-Hemoglobin & & 592 & $26,600-112,011$ & b.d. $-11,000$ \\
\hline $\mathrm{Hb} 2$ & $\beta$-Hemoglobin & & 502 & $136,990-225,649$ & $13,142-79,134$ \\
\hline $\mathrm{Hb} 3$ & $\alpha$-Hemoglobin & & 164 & $172,640-267,198$ & $111,714-146,638$ \\
\hline IIb4 & $\alpha$-Hemoglobin & & 190 & $393,072-555,450$ & $154,824-376,064$ \\
\hline $\mathrm{Hb5}$ & $\alpha$-Hemoglobin & & 252 & $39,838-81,083$ & $13,830-33,376$ \\
\hline Hb6 & $\alpha$-Hemoglobin & & 231 & $14,450-28,898$ & $4,879-13,372$ \\
\hline $\mathrm{Hb} 7$ & $\beta$-Hemoglobin & EFTPPVQAAYQK & 193 & $63,758-98,601$ & $29,323-49,390$ \\
\hline $\mathrm{Hb8}$ & $\beta$-Hemoglobin & & 175 & $198,575-239,153$ & $72,975-171,221$ \\
\hline $\mathrm{Hb} 9$ & $\alpha$-Hemoglobin & & 491 & $39,737-148,715$ & b.d. $-15,083$ \\
\hline 1 & Neurofilament $(67 \mathrm{kDa})$ & DEPPSEGEAE & 283 & $31,601-69,859$ & $6,279-24,896$ \\
\hline 2 & Myelin basic protein & GVDAQGTLSK & 260 & $18,515-26,685$ & $7,093-10,930$ \\
\hline 3 & PEP-19 & AAVAIQSQFR & 282 & $12,994-34,437$ & $5,848-11,201$ \\
\hline 4 & Myelin basic protein & GRGLSLSRFS & 194 & $95,253-152,880$ & $49,367-80,824$ \\
\hline 5 & Calmodulin & AFSLFDKDGDGTI & 191 & $12,857-24,630$ & $7,401-11,111$ \\
\hline 6 & Calmodulin & VFDKDGNGYI & 420 & $76,378-134,813$ & $10,813-61,039$ \\
\hline
\end{tabular}

b.d., below detection. 


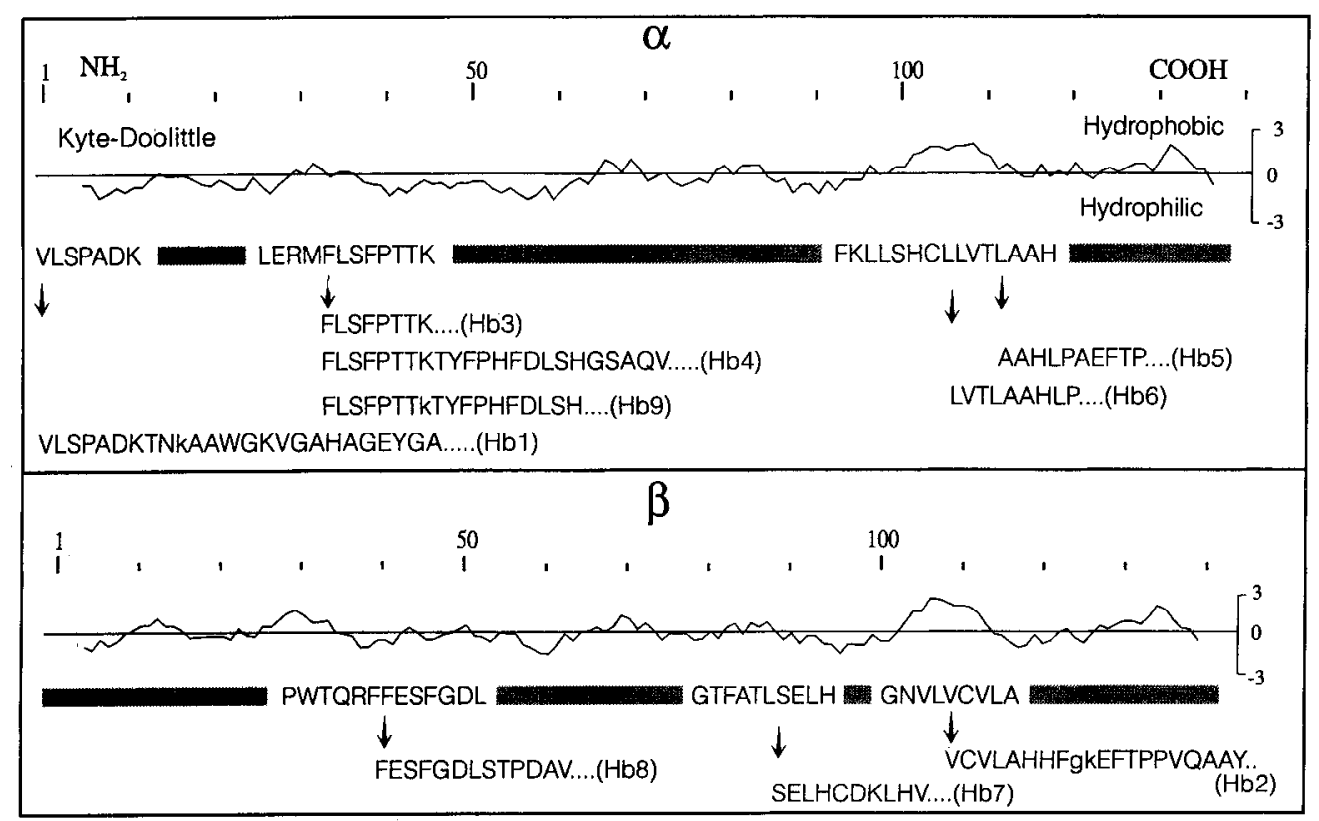

Figure 3. Amino-terminal analysis of the fragments that were derived from hemoglobin. The intact hemoglobin polypeptides identified in this study were open to sequencing by Edman degradation. The hemoglobin sequences from each fragment identified in Figure 2 are shown below the sequence of either intact $\alpha$ - or $\beta$-hemoglobin. The molecular sizes of the hemoglobin-derived peptides are unknown, as are their carboxyl-terminal sequences. With the exception of $\mathrm{Hb} 7$, all other fragments were cleaved approximately $30-40$ residues in from either the amino or carboxyl terminus. As can be seen from the hydropathic plot above the hemoglobin sequence, these correspond to a domain that is predicted to be hydrophobic for the region near the carboxyl side of the intact hemoglobin polypeptides and to a more neutral domain for the region nearer the amino terminus. Uppercase letlers are amino acid residues identified from Edman sequencing, while lowercase letters were deduced from published sequence for the purpose of aligning tryptic fragment sequence with sequence from intact peptides. molecular-weight fraction, were analyzed using our computer programs that can sort homologous peaks into corresponding observations within a spreadsheet. The RP-HPLC traces from the high-molecular-weight fraction are shown in Figure 1. The criterion used for identifying peptide species whose expression was altered in AD was that the range of peak heights between $\mathrm{AD}$ and control cases did not overlap. This highlighted peptides that were either increased or decreased in AD. Only the highmolecular-weight peptides contained species that met this criterion. The profiles of the peptides present in the low-molecularweight material were very similar between the groups, which is consistent with the inherent reproducibility of peptide analyses on RP-HPLC (Slemmon and Flood, 1992). In contrast, the peptide profiles of the high-molecular-weight species were consistent within subject groups, but not between AD and control. Of the just under 100 high-molecular-weight peptide species that could be resolved per sample, 15 were elevated as a function of AD (Table 1). The positions of these peaks on the RP-HPLC chromatograms are summarized in Figure 2. None of the peptides were reduced in the AD samples; however, minor peptide species that become reduced in the presence of increased peaks are difficult to detect in an HPLC-dependent system such as the one employed.

\section{Identification of the peptides that were elevated in $A D$ in the high-molecular-weight peptide fraction}

One of the major advantages of using RP-HPLC to examine tissues for molecular changes is that the peaks are already isolated and amenable to amino-terminal sequencing. Generally, the only extra step may be the generation of fragments of the parent peptide, if sequencing intact peptide is unsuccessful. Table 1 shows the sequences obtained from tryptic fragments and the identification of the protein that contains that sequence. Because of limited material or failure of the purified intact peptide from the screening to yield sequence directly, amino-ter- minal sequence was obtained only from the hemoglobin-derived peptides. Figure 3 shows the alignment of these amino-tcrminal sequences with the hemoglobin polypeptides from which they were derived, thereby locating their position of cleavage. In some cases, amino-terminal sequence from the hemoglobinderived fragments is combined with the sequence of corresponding tryptic fragments to yield a single contiguous sequence. All sequences determined were exact matches for their corresponding source polypeptides as retrieved by searching the GenBank and EMBL data bases (Devereux et al., 1984).

Of the 15 peptides that showed elevated expression, 9 were specific fragments of hemoglobin (Fig. 3). Six were derived from the $\alpha$-chain and three were from the $\beta$-chain. Four of these sequences were derived from the same or similar positions on either $\alpha$ - or $\beta$-hemoglobin, near residue 35 in both polypeptides. Three more were cleaved from positions on the intact hemoglobin just after residue 100 , within a conserved hydrophobic domain. The remaining two peptides represented the amino terminus of the $\alpha$-chain and a structurally unrelated cleavage site near the middle of the $\beta$-sequence ( $\mathrm{Hb} 7$ ). The peptide containing the amino-terminal sequence of a hemoglobin ( $\mathrm{Hb} 1)$ is most likely a smaller fragment, as judged by its early elution time (see Fig. 2) and the expected hydrophilic nature of a fragment from this region of the parent polypeptide. The only striking feature of the primary structure around the amino-terminal cleavage sites for these fragments is the preference for a hydrophobic amino acid residue on the amino-terminal side of the cut. Four of the cleavage sites are after leucine, three are after methionine, and one more is after phenylalanine. The cleavage sites near the amino terminus are all at hydrophobic residues that are adjacent to a basic residue, which in all cases was arginine.

Of the six peptide species that were not hemoglobin derived, two were related to calmodulin, two were related to myelin basic protein, one was related to $67 \mathrm{kDa}$ neurofilament protein, and 

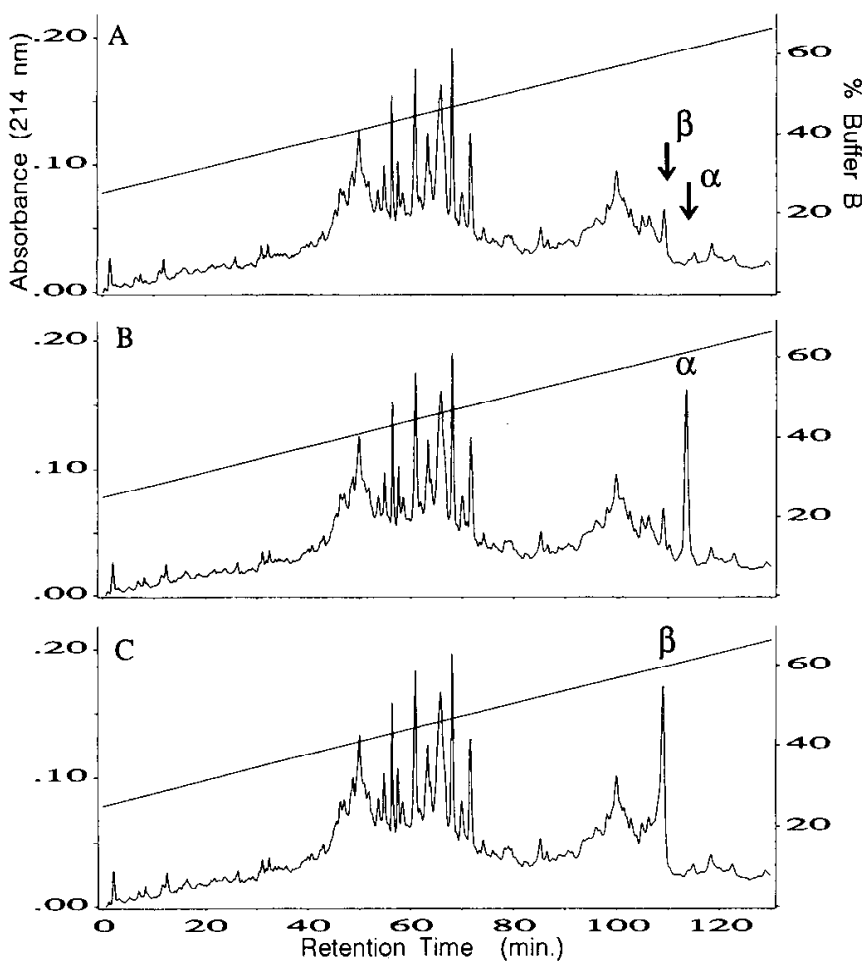

Figure 4. Identification of intact hemoglobin $\alpha$ and $\beta$ by comigration analysis on RP-HPLC. Human hemoglobin was prepared in the same manner that tissue peptides were extracted and the resultant denatured $\alpha$ - and $\beta$-chains werc purificd on RP-HPLC. Identification of the polypeptides was achieved by obtaining 10 cycles of Edman sequencing information on each peptide peak. These peaks were then individually added to aliquots of one of the samples of high-molecular-weight peptides shown in Figure $1 I$. Of the peaks under study, none comigrated with either intact $\alpha$ - or $\beta$-hemoglobin. The peak in $A$ that comigrated with $\beta$-hemoglobin was submitted for sequencing and yielded a major sequence that was unknown and a minor sequence starting at residue I for $\beta$-hemoglobin. Intact $\alpha$-hemoglobin is a smaller shoulder that eluted just ahead of peak $\mathrm{Hb}$.

the last one was from PEP-19 (Ziai et al., 1986). The elution times of the PEP-19 and calmodulin-related peptides within the HPLC profiles strongly suggest that these peptides are the intact parent protein. The structural difference between the two calmodulin peaks is unknown and amino-terminal sequencing was unsuccessful on intact material from these peptides.

\section{Identification of intact $\alpha$ - and $\beta$-hemoglobin polypeptides on $R P-H P L C$}

It was also of interest to determine how much intact hemoglobin was present in the tissues, since the vasculature could contribute a considerable amount of this material to the peptide profile. The positions of the intact hemoglobin chains were determined by observing the migration of these polypeptides within separations of the high-molecular-weight peptides from the cerebellar samples. As can be seen in Figure 4, the intact sequences from hemoglobin do not coelute with any of the peptides under study. The $\alpha$-hemoglobin sequence migrated just ahead of peptide $\mathrm{Hb} 9$, and the $\beta$-hemoglobin polypeptide comigrated with a larger peak that appeared stoichiometrically more abundant than the $\alpha$-chain. This anomaly was explained by submitting the apparent $\beta$-hemoglobin peak to amino-terminal sequencing. A minor sequence was obtained for intact $\beta$-hemoglobin, but the major sequence belonged to an unknown polypeptide. It

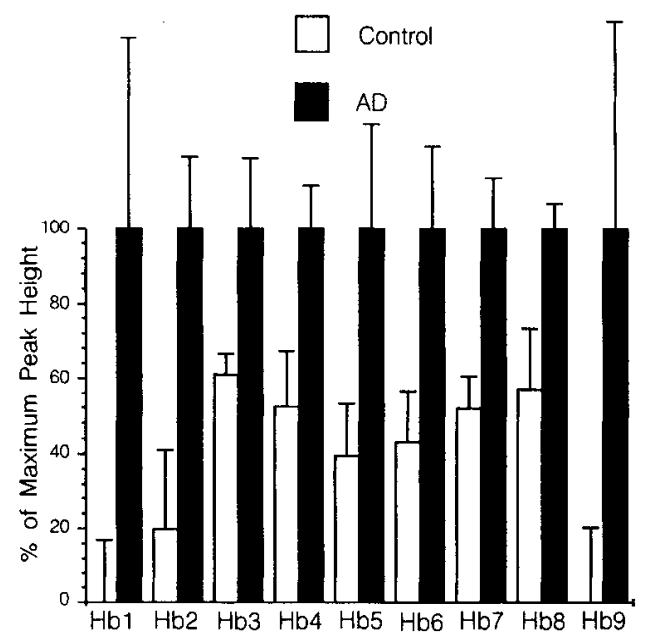

Figure 5. Comparison of the relative change between control and AD cases for the hemoglobin fragments. $H b 1$ and $H b 9$ are $\alpha$-hemoglobinderived fragments and represent the greatest differences between $A D$ and control subjects for this polypeptide. The only fragment from $\beta$-hemoglobin with a similar difference was $\mathrm{Hb} 2$, which is cleaved from nearer the carboxyl terminus of that polypeptide. This site in the native polypeptide is located in the middle of a very hydrophobic region, which would not be expected to display itself near the surface where proteases could have access. Error bars are SD.

appeared that the peptide peak that comigrated with $\beta$-hemoglobin was primarily a nonhemoglobin peptide, with $\beta$-hemoglobin contributing a late eluting shoulder to this peak. It was apparent that relative to the intact hemoglobin polypeptides, the fragments of hemoglobin were also reasonably abundant. This may be a result of the red blood cells in the cerebellar vasculature draining postmortem, causing the fragments in the tissue to become proportionately more enriched.

\section{Comparison of changes in hemoglobin fragmentation as a function of $A D$}

Alterations in protease activities have been suggested to be part of the pathophysiology of $\mathrm{AD}$ in an increasing number of studies. Because of this, it was of interest to identify the cleavages that were most affected in the AD cases. Figure 5 displays the levels of specific hemoglobin fragments in the AD cases relative to their levels in controls, along with the standard deviations of the means. This comparison identified hemoglobin fragments $\mathrm{Hbl}$ and $\mathrm{Hb} 9$, shown in Figure 3, as having the greatest difference for cleavage on the $\alpha$-hemoglobin polypeptide in AD. Since hemoglobin fragment $\mathrm{Hb} 1$ is presumably short, and its relative change is similar to that of fragment $\mathrm{Hb}$, it may be the aminoterminal portion of hemoglobin fragment $\mathrm{Hb} 9$. The most prevalent cleavage site on the $\beta$-chain corresponds to fragment $\mathrm{Hb} 2$, cleaved near the carboxyl terminus of $\beta$-hemoglobin. The only peculiarity for cleavage at this site is that the hydropathic plot indicates the site to be an internal domain, which should not be readily available to proteases unless the molecule were first denatured. This may eventually offer a clue to the sequence of events that generates the fragments from functional hemoglobin.

\section{Localization of hemoglobin-like immunoreactivity in cerebellum}

That intact $\alpha$ - and $\beta$-hemoglobin contributed relatively small amounts of peptide to the profiles, compared to the level of the fragments, was interesting. The vasculature could be expected 
to contribute significant amounts of intact hemoglobin polypeptides if large numbers of red blood cells were present. Postmortem delay might explain the increase in hemoglobin fragments over intact sequences except that the average delay for the controls was $16 \%$ longer, and these samples contained systematically lower levels of the fragments. Also, very few peptides were observed to change as a function of postmortem delay when this parameter was examined in studies carried out in whole rat brain (Slemmon and Flood, 1992), where red blood cells were almost certainly present.

Localization of human hemoglobin-like immunoreactivity, using antibodies raised in rabbit, indicated that relatively few red blood cells remained in postmortem ccrcbcllum blood vessels, thereby at least partially explaining the low levels of intact hemoglobin polypeptides (Fig. 6). Presumably, much of the blood drained from the cerebellum postmortem. The localization further showed patches of hemoglobin-like immunoreactive material on blood vessel walls and staining of about $20-40 \%$ of the granule neurons. The similarity in the intensity of hemoglobinlike immunoreactivity around these neurons compared to that of the red blood cells suggested that considerable peptide had been deposited (Fig. 6A). At higher magnification (Fig. $6 F$ ) the deposit appeared to localize to granule cell membranes. Consistent with the RP-HPLC data, similar staining was observed in age-matched controls, but appeared to be generally less intense (Fig. 6B). In contrast, a 36-year-old control cerebellum showed evident vessel wall localization, but no granule cells were decorated (Fig. 6D). Hemoglobin-like staining was eliminated by first preabsorbing anti-hemoglobin IgG with solidphase hemoglobin (Fig. 6C). These results are consistent with the interpretation that the appearance of hemoglobin-like material in the parenchyma is not only dependent on processes associated with $\mathrm{AD}$, but to a lesser extent on those associated with aging.

Producing antibodies in rabbits to highly conserved proteins such as hemuglobin can be expected to present special problems. Figure 7 shows the comparison of human and rabbit hemoglobin polypeptides. The $\beta$-chains are nearly identical whereas the $\alpha$-chains show more divergence. This can be expected to bias antibody titers toward peptide sequences derived from the amino-terminal half of the $\alpha$-hemoglobin polypeptide. This situation has the potential for allowing restricted immunocytochemical localization of the hemoglobin fragments. It was also observed that human hemoglobin caused significant background staining of granule neurons when exposed to the tissue sections (Fig. $6 E$ ). This, and the potential for interference by rabbit hemoglobin present in the antisera, was the reason that purified IgG was used in place of whole sera. Preadsorption controls were accomplished by using solid-phase hemoglobin, thereby avoiding the problem of exposing the tissue sections to hemoglobin (Fig. 6C).

Western blot analysis of crude human cerebellar proteins using the anti-hemoglobin sera employed for the present study is demonstrated in Figure 8. The homogenates showed only the hemoglobin band at approximately $16 \mathrm{kDa}$. The supernatants contained a minor band at $22 \mathrm{kDa}$ whose identity is unknown. Since the band is not present in the homogenates, it is likely to be a hemoglobin adduct formed during supernatant production such as a mixed disulfide or oxidized hemoglobin polypeptide (Dafré and Reischl, 1990). The Western blutling analysis of human cerebellar proteins indicated that the anti-human hemoglobin sera used in this study appeared to be primarily directed toward hemoglobin. The results of the immunocyto- chemical studies using this antisera were also in general agreement with the predicted amount of hemoglobin protein present in the tissue as demonstrated by peptide analysis.

\section{Discussion}

RP-HPLC was used for analyzing differences in peptide composition between $A D$ and control subjects because proteolytic processing and the deposition of peptides are central features in this disease (Selkoe, 1991). The data presented here have highlighted multiple changes in peptide production in cerebellum that were affected by $\mathrm{AD}$ and identified hemoglobin as a substrate that displays increased proteolysis. Immunocytochemical localization of the hemoglobin-like immunoreactivity demonstrated that the granule cells are the primary site of deposition in the parenchyma and suggested that at least some hemoglobin sequences can evade the blood-brain barrier.

\section{Peptide analysis as a molecular tool}

The methodology used to develop the peptide profiles in the present study can be thought of as a general approach since it can be exploited to look for changes as a function of basically any biological paradigm. The protocol for preparing crude peptides for subsequent analysis in this study and the reliance on classical RP-HPLC limits the type of peptide that can be examined to those that are low $\mathrm{pH}$ soluble and also at least moderately soluble in organic solvent. The low $\mathrm{pH}$ homogenization as a consequence, though, offers the advantage that it blocks artifactual proteolysis, so that the peptides recovered reflect products of endogenous peptide processing. The prefractionation of crude peptides on size exclusion and ion-exchange chromatography greatly enhances the number of species that can be resolved; however, the majority of peptides that can be observed are moderately abundant to abundant species (Slemmon and Flood, 1992). Fortunately, in terms of total cellular protein such species can still be minor, since small acid-soluble proteins and peptides are not the bulk of cellular protein (e.g., Slemmon et al., 1985).

Other approaches commonly used for molecular studies, such as gel electrophoresis or CDNA analysis, cannot predict peptides produced by proteolytic processing. Also, many small proteins and most peptides are not well resolved on gels. As a consequence, peptide analysis studies are a unique addition to these and other techniques already in use for biological studies. Peptide analysis has an additional appeal in that it is well suited to automation; and a considerable technology is in place for exploiting the characterization of peptides such as spray mass spectrometry or gas-phase sequencing.

\section{Changes in non-hemoglobin-derived peptides}

The non-hemoglobin-derived peptides identified in this study are indicative of changes within the cerebellum that are related to stress responses and changes in the dynamics of ncuronal cytoarchitecture. The calmodulin polypeptides were increased $191 \%$ and $420 \%$ over controls. PEP-19, a putative calciumbinding protein (Ziai et al., 1986), was increased almost $300 \%$. The involvement of calmodulin in stress responses is well known and its role as a calcium "muffler" in supporting cellular homeostasis is well characterized (e.g., Thomas et al., 1991). Calmodulin functions as a calcium-controlled modulator of a broad range of cellular processes. Examples include the recovery of cell volume following hypo-osmotic stress (Pierce et al., 1989), the activation of protein kinase II and cytoskeletal alterations 


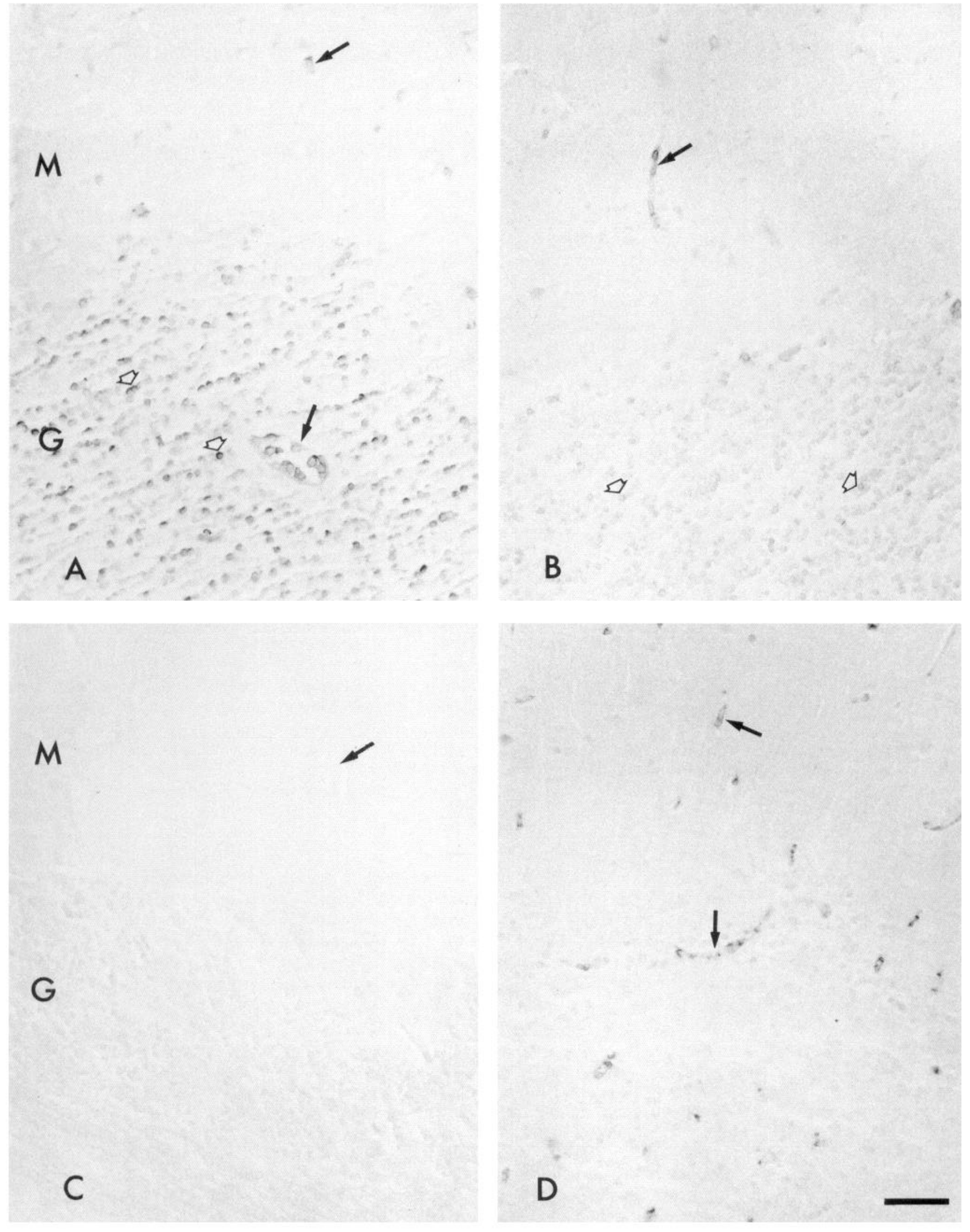

Figure 6. Localization of hemoglobin-like reactivity with IgG against human $\alpha$ - and $\beta$-hemoglobin. $A$, Localization in a 78-year-old AD case (Fig. $1 I)$. This section illustrates typical localization of hemoglobin-like staining in AD cases. Within the molecular layer $(M)$ and granule cell layer $(G)$, many blood vessels are immunoreactive (solid arrows). Within the granule cell layer many, but not all, granule cell neurons are labeled (open arrows). Protein A-purified total IgG from anti-hemoglobin sera was used at $5 \mu \mathrm{g} / \mathrm{ml}$, as for the remainder of the panels. $B$, Localization in an $82-$ 


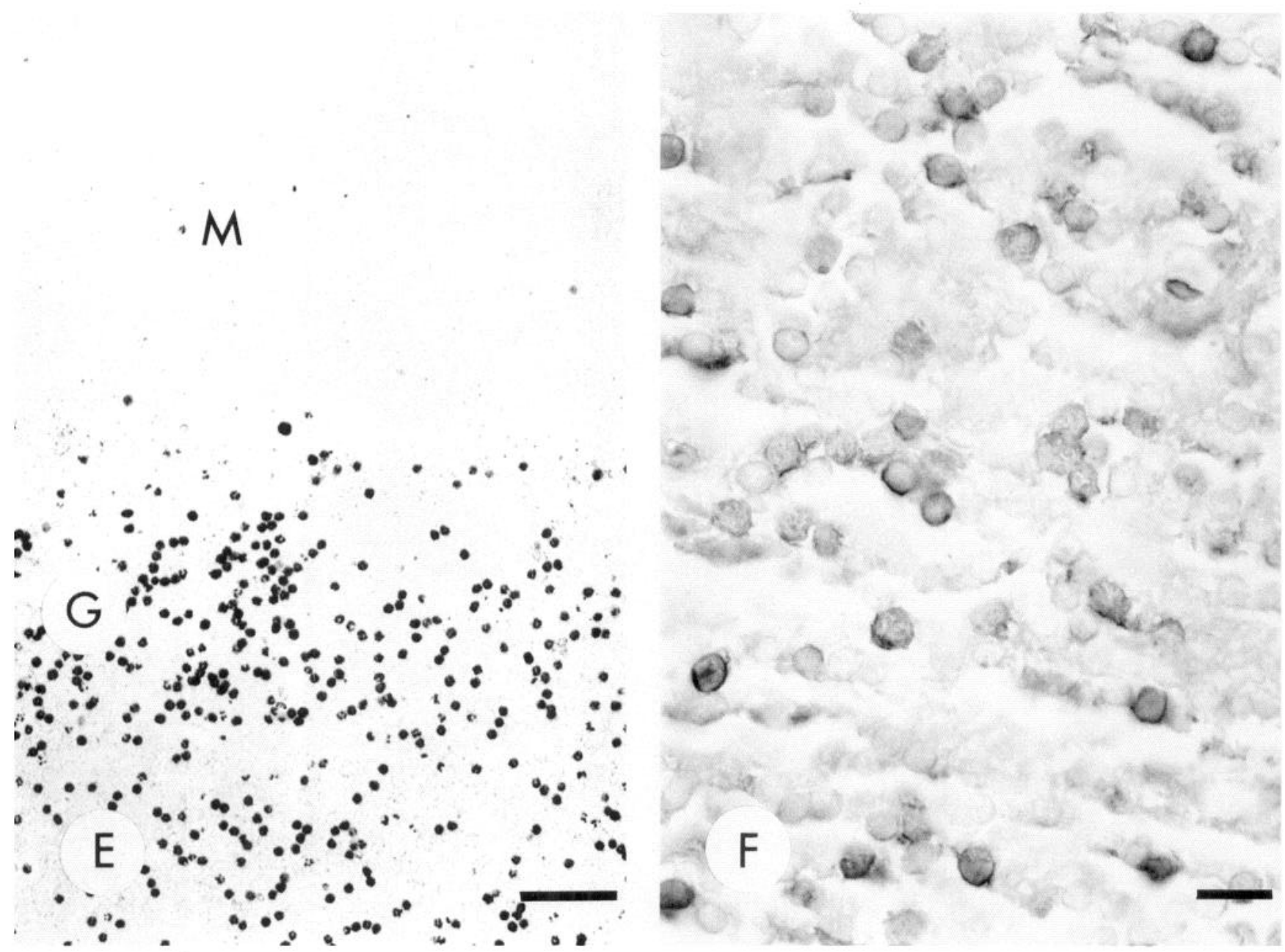

year-old control case (Fig. 1B). The pattern of staining in control cerebellum is similar to that seen in sections from AD cases. The intensity of staining, however, is generally less, which is consistent with the decreased presence of hemoglobin fragments in nondemented controls that can be seen in Figure 1. $C$, AD cerebellum section incubated with IgG from the same preparation used in $A$, only after it had been passed over a solidphase hemoglobin column. Approximately $2 \%$ of total $\mathrm{IgG}$ absorbed to the hemoglobin column. The flow-through IgG from this column was also used at $5 \mu \mathrm{g} / \mathrm{ml}$. Staining of blood vessels and granule cell neurons was effectively eliminated by the removal of anti-human hemoglobin from the total IgG pool. $D$, Localization in a 36-year-old neurologically normal case. Blood vessel staining is apparent, but unlike the older cases virtually no granule cells are immunoreactive. $E$, Section of control ( 73 year old, see Fig. $1 C$ ) cerebellum treated with intact hemoglobin followed by 3,3'diaminobenzidine to show endogenous activity of hemoglobin and its affinity for some granule cells. No binding of hemoglobin to blood vessel walls was seen. $F$, High magnification of the localization of hemoglobin-like immunoreactivity in the case shown in $A$. Many granule cell neurons show a distinct halo of staining on their cell membranes. Scale bars: $A-D, 50 \mu \mathrm{m} ; E, 50 \mu \mathrm{m} ; F, 10 \mu \mathrm{m}$.

following ischemic insult (Onodera et al., 1990), the inhibition of $\mathrm{Ca}^{2+}$ /phospholipid-dependent phosphorylation of proteins such as synapsin I and the $\delta$-subunit of the ACh receptor (Albert et al., 1984), or the phosphorylation of the AD amyloid protein by protein kinase $\mathrm{C}$ and $\mathrm{Ca}^{2+} /$ calmodulin-dependent protein kinase II (Gandy et al., 1988). Increased activity of calmodulin has also been suggested to be necessary for cellular death in cultured renal cells during anoxia (Schwertschlag et al., 1986) and for programmed cell death during the apoptosis of lymphocytes (Dowd et al., 1991). The increase observed in this study for calmodulin peptides in AD cerebellum is therefore suggestive of a condition that can promote cellular decay and is consistent with the increased presence of dystrophic Purkinje cells (Mehraein et al., 1975; Mann et al., 1980) and senile plaques (Braak et al., 1989; Dickson et al., 1990; Mann et al., 1990) in this brain region in $\mathrm{AD}$.

Although mRNA for $68 \mathrm{kDa}$ neurofilament protein has been reported to be relatively unchanged in AD cerebellum (Som- erville et al., 1991), the results of this study indicated that at least one fragment of the protein was elevated by $283 \%$. Myelin basic protein was also elevated $280 \%$ in $\mathrm{AD}$, which is consistent with specific changes in the expression of structural proteins that are required for neuronal function. The extent to which neuron-associated proteins were found to be altered in AD cerebellum was further highlighted by the elevation of PEP-19, a peptide found only in Purkinje and stellate cells in cerebellum (Ziai et al., 1986). Together, these measurements support the conclusion that neuronal metabolism in cerebellum is affected by AD pathophysiology.

\section{Studies suggest that hemoglobin potentiates nervous system damage}

It has been appreciated for some time that hemoglobin is associated with increased insult to the nervous system after trauma. Acute introduction of this heme-containing protein can promote prolonged inflammation (Means and Anderson, 1983) 
$\alpha$ hemoglobin comparison:

1 VLSPADKTNVKAAWGKVGAHAGEYGAEALERMFLSFPTTKTYFPHFDLSH 50 ||||||||$|:| \cdot||:|:| \cdot|:|||||||:|||||:||||||||||||:|$

1 VLSPADKTNIKTAWEKIGSHGGEYGAEAVERMFLGFPTTKTYFPHFDFTH 50

51 GSAQVKGHGKKVADALTNAVAHVDDMPNALSALSDLHAHKLRVDPVNFKL 100 ||$.|:|:|||||.:||| \cdot||:|:||:| \cdot|||\cdot||||||||||||||| \mid$

51 GSEQIKAHGKKVSEALTKAVGHLDDLPGALSTLSDLHAHKLRVDPVNFKL 100

101 LSHCLLVTLAAHLPAEFTPAVHASLDKFLASVSTVLTSKYR 141

||||||||||.| |.|||||||||||||||.||||||||||

101 LSHCLLVTLANHHPSEFTPAVHASLDKFLANVSTVLTSKYR 141

$\beta$ hemoglobin comparison:

1 VHLTPEEKSAVTALWGKVNVDEVGGEALGRLLVVYPWTQRFFESFGDLST 50 ||$|\ldots|||||||||||||||||||||||||||||||||||||||$

1 VHLSSEEKSAVTALWGKVNVEEVGGEALGRLLVVYPWTQRFFESFGDLSS 50

51 PDAVMGNPKVKAHGKKVLGAFSDGLAHLDNLKGTFATLSELHCDKLHVDP 100 $::|||\cdot|||||||||||:|||:||\cdot||||||||||\cdot||||||||||| \mid$ 51 ANAVMNNPKVKAHGKKVLAAFSEGLSHLDNLKGTFAKLSELHCDKLHVDP 100

101 ENFRLLGNVLVCVLAHHFGKEFTPPVQAAYQKVVAGVANALAHKYH 146 1111111111.11 .111111111 .11111111111111111111

101 ENFRLLGNVLVIVLSHHFGKEFTPQVQAAYQKVVAGVANALAHKYH 146

Figure 7. Comparison of $\alpha$ - and $\beta$-hemoglobin polypeptides from human (top rows) and rabbit (bottom rows). Immunocytochemical localization of antigens in tissue sections that are closely related to the specie in which the antibodies were developed can present special problems. It is reasonable to expect that the primary titers will favor the regions of greatest divergence. In this case, the localization of hemoglobinderived peptides in Figure 6 would favor species that contain the aminoterminal half of $\alpha$-hemoglobin. The remainder of the comparison showed that there are, for the most part, infrequent amino acid changes that would not be expected to elicit substantial immune recognition.

or mediate cellular damage through its ability to catalyze lipid peroxidation (Sadrzadeh et al., 1984; Panter et al., 1985). Hemoglobin has also been demonstrated to be toxic to cerebellar granule cells in primary culture (Sadrzadeh et al., 1987), at least in part through the heme moiety. The heme, however, is probably not the only toxic component in the neurodegenerative process of granule cells. For example, both hemoglobin and methemoglobin show the same ability to promote the NMDA-mediated depolarization of granule neurons in the presence of the nitric oxide donor nitroferricyanide (East et al., 1991). Since met-hemoglobin demonstrates seriously impaired heme function, the equal potencies of the two forms of hemoglobin suggest that the action of hemoglobin can also rest in the polypeptide chains.

\section{Implication for accelerated movement of hemoglobin fragments}

One consequence of the proteolysis on the parent polypeptides of $\alpha$ - and $\beta$-hemoglobin may be an accelerated translocation of these sequences into the parenchyma. Generally, peptides and proteins are not able to cross the blood-brain barrier. This, however, can be overcome by receptor-mediated processes (e.g., Banks et al., 1990), increased diffusion of peptides possessing hydrophobic characteristics (e.g. Banks and Kastin, 1985a) and smaller size (Raeissi and Audus, 1989), or the administration of aluminum (Banks and Kastin, 1985b). It could be expected that at least some of the hemoglobin fragments would diffuse more rapidly across the blood-brain barrier than the parent protein. An important question toward characterizing this possibility will be to determine if the bulk of the proteolysis of the hemoglobin protein occurs in the blood, at the endothelial wall, or once the polypeptides have entered the parenchyma. Erythrocytes in patients with $\mathrm{AD}$ have been reported to contain more

\subsection{7 $66.2 \div$}
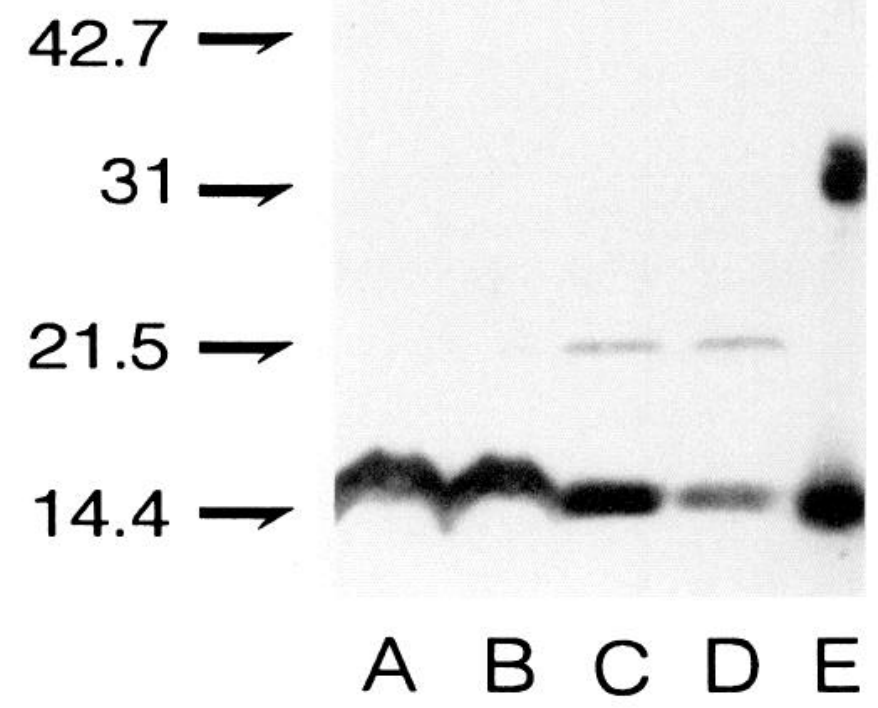

Figure 8. Analysis of crude human cerebellar proteins with Western blotting. Lane $A$ (AD, Fig. $1 G$ ) and lane $B$ (control, Fig. $1 D$ ) show the immunopositive bands produced by anti-human hemoglobin antisera ( $\times 1000)$ on $100 \mu \mathrm{g}$ of total protein. Lanes $C(\mathrm{AD})$ and $D$ (control) are soluble proteins recovered from a supernatant prepared from parallel tissue samples to those used to prepare the homogenates. Lane $E$ is purified hemoglobin standard obtained from a commercial vendor. The analysis showed hemoglobin dimer in the standard and a new band that appeared in the supernatant after homogenization, in addition to the major bands at the position of hemoglobin polypeptide. The apparent difference in band intensity for hemoglobin in lanes $C$ and $D$ is most likely a Western blot artifact since the homogenates from the same cases do not indicate a difference. Hemoglobin can also show variations in band sharpness on electrophoresis in SDS.

surface-bound IgG and display increased proteolysis of cellular protein (Bosman et al., 1991). Oxidative stress has also been reported to cause increases in erythrocyte degeneration (Leclerc et al., 1988). These conditions have the potential for increasing the production of hemoglobin fragments either in the blood plasma or at the endothelial wall. Such fragments could then diffuse into the parenchyma.

\section{Conclusion}

The analysis of peptide expression in cerebellum as a function of $\mathrm{AD}$ has provided information that is consistent with the expectation that this region is affected by the disease. The parallel observations provided by the peptide analyses that elevated fragmentation of hemoglobin is occurring in $\mathrm{AD}$ along with changes in parenchymal cellular metabolism have suggested that proteolysis of proteins that originate in the periphery may be one mechanism by which brain regions can be subjected to stress. Such a process would then have the potential for influencing neuron survival. As a consequence it will be of interest to evaluate the levels of hemoglobin fragments, as well as other peptides, in brain regions that are more affected by AD. Of special interest will be to determine if the proteolysis of hemoglobin occurs in the vasculature, at the vessel wall, or in the 
brain parenchyma, and whether these proteolytic fragments contribute to neurodegeneration in AD.

\section{References}

Abraham CR, Selkoe DJ, Potter H (1988) Immunochemical identification of the serine protease inhibitor $\alpha_{1}$-antichymotrypsin in the brain deposits of Alzheimer's disease. Cell 52:487-501.

Albert KA, Wu WC-S, Nairn AC, Greengard P (1984) Inhibition by calmodulin of calcium/phospholipid-dependent protein phosphorylation. Proc Natl Acad Sci USA 81:3622-3625.

Backstrom JR, Miller CA, Tökés ZA (1992) Characterization of neutral proteinases from Alzheimer-affected and control brain specimens: identification of calcium-dependent metalloproteinases from the hippocampus. J Neurochem 58:983-992.

Banks WA, Kastin AJ (1985a) Peptides and the blood-brain barricr: lipophilicity as a predictor of permeability. Brain Res Bull 15:287292.

Banks WA, Kastin AJ (1985b) The aluminum-induced increase in blood-brain barrier permeability to delta-sleep-inducing peptide occurs throughout the brain and is independent of phosphorus and acetylcholinesterase levels. Psychopharmacology 86:84-89.

Banks WA, Schally AV, Barrera CM, Fasold MB, Durham DA, Csernus VJ, Groot K, Kastin AJ (1990) Permeability of the murine bloodbrain barrier to some octapeptide analogs of somatostatin. Proc Natl Acad Sci USA 87:6762-6766.

Bosman GJCGM, Bartholomeus IGP, De Man AJM, Van Kalmthout PJC, De Grip WJ (1991) Erythrocyte membrane characteristics indicate abnormal cellular aging in patients with Alzheimer's disease. Neurobiol Aging 12:13-18.

Braak H, Braak E, Bohl J, Lang W (1989) Alzheimer's disease amyloid plaques in the cerebellum. J Neurol Sci 93:77-288.

Dafré AL, Reischl E (1990) High hemoglobin mixed disulfide content in hemolysates from stressed shark. Comp Biochem Physiol 96B: 215-219.

Devereux J, Haeberli P, Smithies O (1984) A comprehensive set of sequence analysis programs for the VAX. Nucleic Acids Res 12:387395.

Dickson DW, Wertkin A, Mattiace LA, Fier E, Kress Y, Davies P, Yen SH (1990) Ubiquitin immunoelectron microscopy of dystrophic neurites in cerebellar senile plaques of Alzheimer's disease. Acta Neuropathol (Berl) 79:486-493.

Dowd DR, MacDonald, PN, Komm BS, Haussler MR, Miesfeld R (1991) Evidence for early induction of calmodulin gene expression in lymphocytes undergoing glucocortocoid-mediated apoptosis. J Biol Chem 266:18423-18426.

East SJ, Batchelor AM, Garthwaite J (1991) Selective blockade of $N$-methyl-D-aspartate receptor function by the nitric oxide donor, nitroprusside. Eur J Pharmacol 209:1 19-121.

Gandy S, Czernik AJ, Greengard P (1988) Phosphorylation of Alzheimer disease amyloid precursor peptide by protein kinase $C$ and $\mathrm{Ca}^{2+} /$ calmodulin-dependent protein kinase II. Proc Natl Acad Sci USA 85:6218-6221.

Haltia M, Prelli F, Ghiso J, Kiuru S, Somer H, Palo J, Frangione B (1990) Amyloid protein in familial amyloidosis (Finnish type) is homologous to gelsolin, an actin-binding protein. Biochem Biophys Res Commun 167:927-932.

Ishii T, Haga S (1976) Immuno-electron microscopic localization of immunoglobulins in amyloid fibrils of senile plaques. Acta Neuropathol (Berl) 36:243-249.

Ishii T, Haga S, Shimizu F (1975) Identification of components of immunoglobulins in senile plaques by means of fluorescent antibody technique. Acta Neuropathol (Berl) 32:157-162.

Kalaria RJ, Grahovac I (1990) Serum amyloid P immunoreactivity in hippocampal tangles, plaques and vessels: implication for leakage across the blood-brain barrier in Alzheimer's disease. Brain Res 516: 349-353.

Khatchaturian ZS (1985) Diagnosis of Alzheimer's disease. Arch Neurol 42:1097-1105.

Koh J-Y, Yang LL, Cotman CW (1990) $\beta$-Amyloid protein increases the vulnerability of cultured cortical neurons to excitotoxic damage. Brain Res 553:315-320.

Leclerc L, Vasseur C, Bursaux E, Marden M, Poyart C (1988) Inhibition of membrane erythrocyte $\left(\mathrm{Ca}^{2+}+\mathrm{Mg}^{2+}\right)$-ATPase by hemin. Biochem Biophys Acta 946:49-56.

Mann DMA, Yates PO, Stamp JE, Lincoln J, Toper S (1980) Changes in nerve cells of the human cerebellum in senile dementia. J Clin Exp Gerontol 2:7-22.

Mann DMA, Hones D, Prinja D, Purkiss MS (1990) The prevalence of amyloid A4 protein deposits within the cerebral and cerebellar cortex in Down's syndrome and Alzheimer's disease. Acta Neuropathol (Berl) 80:318-327.

Means ED, Anderson DK (1983) Neurophagia by leukocytes in experimental spinal cord injury. J Neuropathol Exp Neurol 42:707719.

Mehraein P, Yamada M, Tarnowska-Dzidusko E (1975) Quantitative study on dendrites and dendritic spines in Alzheimer's disease and senile dementia. In: Advances in neurology, Vol 12, Physiology and pathology of dendrites (Kreutzberg GW, ed), pp 453-458. New York: Raven.

Milward EA, Papadopoulos R, Fuller SJ, Moir RD, Small D, Beyreuther K, Masters CL (1992) The amyloid protein precursor of Alzheimer's disease is a mediator of the effects of nerve growth factor on neurite outgrowth. Neuron 9:129-137.

Onodera H, Hara H, Kogure K, Fukunaga K, Ohta Y, Miyamoto E (1990) $\mathrm{Ca}^{2+} /$ calmodulin-dependent protein kinase II immunoreactivity in the hippocampus after forebrain ischemia. Neurosci Lett 113:134-138.

Panter SS, Sadrzadeh SMH, Hallaway PE, Haines JL, Anderson VE, Eaton JW (1985) Hypohaptoglobinemia: association with familial epilepsy. J Exp Med 161:748-754.

Pierce SK, Politis AD, Cronkite DH, Rowland LM, Smith LH Jr (1989) Evidence of calmodulin involvement in cell volume recovery and following hypo-osmotic stress. Cell Calcium 10:159-169.

Raeissi S, Audus KL (1989) In-vitro characterization of blood-brain barrier permeability to delta sleep-inducing peptide. J Pharm Pharmacol 41:848-852.

Sadrzadeh SMH, Graf E, Panter PE, Hallaway PE, Eaton JW (1984) Hemoglobin: a biologic Fenton reagent. J Biol Chem 259:1435414356.

Sadrzadeh SMH, Anderson DK, Panter SS, Hallaway PE, Eaton JW (1987) Hemoglobin potentiates central nervous system damage. J Clin Invest 79:662 -664.

Saitoh T, Sundsmo M, Roch J-M, Kimura N, Cole G, Schubert D, Oltersdorf T, Schenk DB (1989) Secreted form of amyloid $\beta$ protein precursor is involved in the growth regulation of fibroblasts. Cell 58 : 615-622.

Schwertschlag U, Schrier RW, Wilson P (1986) Beneficial effects of calcium channel blockers and calmodulin binding drugs on in vitro renal cell anoxia. J Pharmacol Exp Ther 238:119-124.

Selkoe DJ (1991) The molecular pathology of Alzheimer's disease Neuron 6:487-498.

Siman R, Card JP, Davis LG (1990) Proteolytic processing of $\beta$-amyloid precursor by calpain I. J Neurosci 10:2400-2411.

Slemmon JR, Flood DG (1992) Profiling of endogenous brain peptides and small proteins: methodology, computer-assisted analysis and application to aging and lesion models. Neurobiol Aging 13:649-660.

Slemmon JR, Danho W, Hemstead JL, Morgan JI (1985) Cerebellin: a quantifiable marker for Purkinje cell maturation. Proc Natl Acad Sci USA 82:7145-7148.

Smith RP, Higuchi DA, Broze GJ Jr (1990) Platclet coagulation factor XIa-inhibitor, a form of Alzheimer amyloid precursor protein. Science 248:1126-1128.

Somerville MJ, Percy ME, Bergeron C, Yoong LKK, Grima EA, McLachlan DRC (1991) Localization and quantitation of $68 \mathrm{kDa}$ neurofilament and superoxide dismutase- 1 mRNA in Alzheimer brains. Mol Brain Res 9:1-8.

Thomas RC, Coles JA, Deitmer JW (1991) Homeostatic muffling. Nature 350:564.

Whitson JS, Selkoe DJ, Cotman CW (1989) Amyloid $\beta$ protein enhances the survival of hippocampal neurons in vitro. Science 243: $1488-1490$.

Wisniewski HM, Kozlowski PB (1982) Evidence for blood-brain barrier changes in senile dementia of the Alzheimer type (SDAT). Ann NY Acad Sci 396:119-129.

Yankner BA, Dawes LR, Fisher S, Villa-Komaroff L, Oster-Granite ML, Neve RL (1989) Neurotoxicity of a fragment of the amyloid precursor associated with Alzheimer's disease. Science 245:417-420.

Ziai R, Pan EY-C, Hulmes JD, Sangameswaran L, Morgan JI (1986) Isolation, sequence, and developmental profile of a brain-specific polypeptide, PEP-19. Proc Natl Acad Sci USA 83:8420-8423. 